\title{
Changes in Nutrients, Energy, Antioxidant and Carotenoid Levels of Dried Tomato (Lycopersicon esculentum) Pomage Treated with Aspergillus niger Solid-State Fermentation
}

\author{
Kerim Demirgül ${ }^{1, a}$, Ergin Özturk ${ }^{2, b, *}$ \\ ${ }^{1}$ Department of Animal Science, Institute of Sciences, Ondokuz Mayls University, 55139 Samsun, Turkey \\ ${ }^{2}$ Department of Animal Science, Faculty of Agriculture, Ondokuz, Mayis University, 55270 Samsun, Turkey \\ *Corresponding author
}

\begin{tabular}{|c|c|}
\hline A R T I C L E I N F O & A B S T R A C T \\
\hline $\begin{array}{l}\text { Keywords: } \\
\text { Antioxidant } \\
\text { Carotenoids } \\
\text { Microbial fermentation } \\
\text { Nutrients } \\
\text { Tomato pomace }\end{array}$ & $\begin{array}{l}\text { Tomato pomace (TP), utilized improperly is not namely causes a waste of valuable resources but } \\
\text { also increases environmental pollution. In this study, possibilities improving nutrient composition } \\
\text { by fermenting dry TP with Aspergillus niger was investigated for the value-added utilization of this } \\
\text { pomace in animal feed. The TP, dried at } 65^{\circ} \mathrm{C} \text { for } 8 \text { hours with a simple layer and under a laminar } \\
\text { airflow drying oven, was subjected to solid-state fermentation. After unfermented and fermented } \\
\text { dry pomaces were milled in } 2 \mathrm{~mm} \text { sieve, proximate analysis and the analysis of cellulosic fractions } \\
\text { were performed. Roughage quality indices were calculated using cellulosic fractions. Fermentation } \\
\text { of TP with Aspergillus niger inoculant increased the amount of dry matter ( } 82.98 \text { vs } 91.47 \%) \text {, crude } \\
\text { fiber ( } 21.71 \text { vs } 23.00 \%) \text {, neutral detergent fiber }(29.70 \text { vs } 35.92 \%) \text {, acid detergent fiber }(25.22 \text { vs } \\
26.84 \%) \text { acid detergent lignin ( } 7.91 \text { vs } 10.77 \%) \text {, hemicellulose ( } 44.71 \text { vs } 90.78) \text {, crude protein } \\
(13.70 \text { vs } 21.37 \%) \text {, ether extract }(2.82 \text { vs } 3.52 \%) \text { and ash (10.57 vs } 13.24 \%) \text { compare to } \\
\text { unfermented TP. Fermentation process decreased nitrogen-free extract ( } 51.19 \text { vs } 38.86 \%) \text {, non-fiber } \\
\text { carbohydrates ( } 46.03 \text { vs } 29.47 \%) \text { and quality index as relative feed value }(216.9 \text { vs } 176.1) \text { and } \\
\text { relative forage quality ( } 242.5 \text { vs } 195.5) \text { and metabolizable energy }(2.66 \text { vs } 2.60) \text {. Ferric reducing } \\
\text { antioxidant power (FRAP), DPPH free radical (2,2-diphenyl-1-picrilhydrazil) and total phenolic } \\
\text { content of TP did not increase by fermentation. Concentration of } \beta \text {-carotene and lycopene of TP } \\
\text { decreased after fermentation with A niger. The results indicate that the selected strains of A. niger } \\
\text { can be used to enrich the chemical composition of TP, except for cellulosic fractions and also } \\
\text { carotenoids and antioxidant activity. }\end{array}$ \\
\hline
\end{tabular}

\section{This work is licensed under Creative Commons Attribution 4.0 International License}

Introduction

The tomato is one of the most widespread fruits in the world and is produced around $1.8-2.0 \times 10^{8}$ tonnes per annum (FAO 2019). A small portion of tomato, which is a seasonal fruit, is consumed as fresh by humans. The majority of tomatoes is processed to tomato paste, ketchup, fruit juice, sauce, puree etc. (Kaur et al., 2008). In this way, the remaining tomato pomace (TP) compose of around 3$7 \%$ of tomato, that consists mainly of peels, seeds and a small amount of pulp (Zuorro et al., 2011). All of the TP produced worldwide (estimate 5.4-9.0 $\times 106$ tons, Lu et al., 2019) have to evaluate at the time required as feed or food, because TP with high water content (about 95\%) is not suitable for long-term storage (Demiray 2009). This not only increases environmental pollution, but also causes waste of valuable resources (Lu et al., 2019).

TP is a good source of protein, oil, lycopene, carotenoids, dietary fibre, pectin and polyphenolics (Nour et al., 2018). The high fiber content results in poor digestibility, worse feed utilization and low metabolizable energy value of animal and especially poultry diets (Ozturk 2017). Solid-state fermentation (SSF) is one of the alternatives and effective methods that can be used to obtain richer nutrient-containing ration components (Gungor and Erener 2020a). By fermentation, the antinutritional elements of the feed can be removed, reducing the amount of tannins, degrading cellulose structures, enriching with enzymes, phenolic compounds, organic acids and color substances and increasing nutritional composition (Gungor et al., 2017; Altop, 2019a; Gungor and Erener, 2020b).

As a result of solid-state fermentation of tomato pomace with A. niger, it was found that acid detergent fiber (ADF), crude fiber (CF), lignin and neutral detergent fiber (NDF) content decreased significantly and dry matter (DM), nitrogen-free extract (NFE), ether extract (EE), ash, crude protein (CP) and metabolizable energy (ME) increased (Tosun 2017). It was reported that tannin, which is one of the antibacterial factors, decreased by $86-89 \%$. 
The optimization of some parameters such as the choice of suitable microorganisms and substrates in the isolation and purification of the product has a beneficial effect on the efficiency and yield of the SSF (Altop, 2019b). In previous studies, it has reported that ATCC 9142, ATCC 200345 and ATCC 52172 strains decreased CF, NFE, NDF and ADF amounts (Gungor et al., 2017), but the ether extract content did not change (Aguilar et al., 2008; Okpako et al 2008; Lawal et al., 2010). In contrast, in some studies, SSF decreased ether extract (Kayode and Sani, 2008; Apata, 2011) and ash content (Kayode and Sani, 2008). Moreover, it is known that microorganisms reduce the NFE content of the substrate using easily soluble carbohydrates in the substrate. However, ATCC® 9029 ${ }^{\mathrm{TM}}$ strain increased the content of NFE in TP (Tosun, 2017) and in Terminalia catappa fruit meal (Apata et al., 2011), respectively. These reports indicate that the efficiency of SSF depends on mainly two factors with, related to SFF such as microorganism type or strain, $\mathrm{pH}$ and moisture of culture medium and with substrates such as cultivars, season, or processing, including the nutritive value. There is no enough information on whether SSF application using $A$. niger (ATCC $® 200345$ TM) affects the nutrient content and quality of the pomace from Tokat tomato, one of the most quality cultivars in terms of marketable food products and nutritive value. Therefore, in this research, it was puposed to determine how the nutrient content of dry tomato pomace was affected by SSF application using $A$. niger $\left(\mathrm{ATCC}^{\circledR} 200345^{\mathrm{TM}}\right)$.

\section{Materials and Methods}

\section{Collection of Samples}

Freshly harvested tomatoes were collected and put in the container, washed to remove dirts, chopped into small pieces with a knife. In order to remove the juice of the roughly crushed tomatoes, it was squeezed through a sieve with a diameter of $1 \mathrm{~mm}$. The remaining part of the sieve was used as tomato pomace.

\section{Drying and Nutrient Analysis of Tomato Pomace}

The TP was dried in an air-circulating oven in trays at $65^{\circ} \mathrm{C}$ for 8 hours. The dried TP was milled through a $2 \mathrm{~mm}$ hole diameter sieve and mixed homogeneously. Three samples of tomato material were put to the laboratory and stored at $-20^{\circ} \mathrm{C}$ until further proccess for determination of antioxidant level and total phenolic content.

\section{Fermentation of Dried Tomato Pomace}

In solid state fermentation, dry TP from Tokat tomato and Aspergillus niger (ATCC ${ }^{\circledR} 200345^{\mathrm{TM}}$ ) obtained from the American Type Culture Collection was used as a substrate and inoculant, respectively. In the study, $6 \mathrm{~kg}$ pomace with a DM content of $90 \%$ were divided in 6 equal parts and allocated to 2 treatment groups with 3 replications. These TP samples were ground and then sterilized in an autoclave at $121^{\circ} \mathrm{C}$ for 15 minutes. After $A$. niger microorganism was cultured for 7 days at $24^{\circ} \mathrm{C}$ in potato dextrose agar (PDA), the bacteria count was made by a Thoma slide and a suspension of $10^{4}$ spores $/ \mathrm{ml}$ was prepared. Then A. niger spore was propagated to ferment the second TP group in a sterile cabinet. In order to provide an environment suitable for the operation of $A$. niger, a mixture of nutritional salt with $60 \%$ humidity was applied. A nutritional salt $\left((\mathrm{NH} 4)_{2} \mathrm{SO} 4\right.$ : glucose: $\mathrm{KH}_{2} \mathrm{PO}_{4}$ : urea: $\mathrm{MgSO}_{4} \cdot 7 \mathrm{H}_{2} \mathrm{O}$ : peptone $\left.=6: 4: 4: 2: 1: 1\right)$ of $180 \mathrm{~g}$ was added to $1600 \mathrm{cc}$ of distilled water to ensure that the mixture contained $60 \%$ moisture. This fermentation media was calibrated to pH 5 using $1 \mathrm{~N} \mathrm{NaOH}$ and $\mathrm{HCl}$. Thus TP samples were incubated at $30^{\circ} \mathrm{C}$ for 72 hours. Then they spread on polyethylene paper and dried to $90 \%$ dry matter at room temperature. At the end of the drying process, they were ground to $2 \mathrm{~mm}$ for proximate analyses.

\section{Analysis of Proximate}

The samples obtained at the end of fermentation were dried in the oven $\left(30-50^{\circ} \mathrm{C}\right)$ and then, DM, ash, CP, EE, CF analyzes was made according to Weende analysis method. Also, these nutrient ingredients were analysed in the dried TP before fermentation. ADF, NDF and acid detergent lignin (ADL) analyzes were performed (A2000, Ankom) considering Van Soest et al. (1991). Hemicellulose was calculated as NDF minus ADF. Quantity of NFE was calculated on a dry weight basis by subtracting the percentages of $\mathrm{CP}, \mathrm{EE}, \mathrm{CF}$ and ash from $100 \%$. The Relative Feed Value (RFV) index assumes digestible dry matter (DDM) of the alfalfa from ADF, and calculates the DM intake potential from NDF. The index is then calculated as DDM multiplied by dry matter intake (DMI as a $\%$ of BW) and divided by 1.29 . This index sorts the forages according to the digestible DMI of full bloom alfalfa (Jeranyama and Garcia, 2004). Total digestible nutrients (TDN) substitutes and DDM is used for the Relative Forage Quality (RFQ) calculation. Feed intake and TDN values are estimated from fiber digestibility provided in the laboratory. The RFQ was calculated as follows (Undersander 2003):

$$
\mathrm{RFQ}=(\mathrm{DMI}, \% \text { of } \mathrm{BW}) \times(\mathrm{TDN}, \% \text { of } \mathrm{DM}) / 1.23
$$

The value of 1.23 ensures the equation has an average and range similar to that of RFV. TDN, DE and ME were calculated according to Alves et al. (2011).

$$
\begin{aligned}
& \mathrm{TDN}=102.56-(1.14 \times \mathrm{ADF}) . \\
& \mathrm{DE}=\mathrm{TDN} \times 0.044 . \mathrm{ME}=\mathrm{DE} \times 0.82 .
\end{aligned}
$$

\section{Determination of Total Phenolic Content}

Dried plant materials were extracted with $75 \mathrm{~mL}(95 \%$ $\mathrm{v} / \mathrm{v}$ ) ethanol at $40^{\circ} \mathrm{C}$ for $10 \mathrm{~min}$; the extraction process was repeated thrice. The solvent was evaporated at $40^{\circ} \mathrm{C}$ under reduced pressure. Dried extract was used in later analysis. The total phenolic content of TP and fermented tomato pomage (FTP) extracts was determined using Folin and Ciocalteu reagent, following the spectrophotometric method described by Singleton and Rossi (1965) via small modifications. The test sample $(200 \mu \mathrm{L}$ of diluted extract) was mixed with $1 \mathrm{~mL}$ of $0.2 \mathrm{~N}$ Folin-Ciocalteu's phenol reagent and left in the dark for eight minutes. Then $2 \mathrm{~mL}$ of saturated sodium carbonate $(75 \mathrm{~g} / \mathrm{L}, 7.5 \% \mathrm{w} / \mathrm{v}$ in water) was added, the mixture was shaken and kept in the dark. After a 2-2.5 hour reaction at room temperature, the absorbance of all samples was measured at $760 \mathrm{~nm}$ with a UV-spectrophotometer. The phenolic content was calculated as gallic acid equivalents $(\mathrm{GAE} / \mathrm{g})$ of dry plant material on the basis of a standard gallic acid curve (5-500 
$\left.\mathrm{mg} / \mathrm{L}, \quad Y=0.0027 x-0.0055, R^{2}=0.9999\right)$. All appointments were done three times.

\section{Determination of Total Flavanoids}

The total flavonoid ingredient of the unfermented and fermented dry tomato pomages was made according to the aluminum chloride colorimetric method with some modifications (Verzelloni et al., 2007). One $\mathrm{mL}$ sample was mixed with $0.3 \mathrm{~mL}$ of $5 \% \mathrm{NaNO}_{2}$ solution, and after kept for five minutes, $0.5 \mathrm{~mL}$ of $2 \% \mathrm{AlCl}_{3}$ was added. This mixture was neutralized with $1 \mathrm{M} \mathrm{NaOH}$, and after 10 minutes, the optic density at $510 \mathrm{~nm}$ was measured. The results are expressed in terms of catechin equivalent.

\section{Determination of Antioxidant Activity}

The extracts were dissolved in $80 \%$ methyl alcohol to obtain a $20 \mathrm{mg} / \mathrm{mL}$ stock solution. The antioxidant activity of the extracts was measured at a concentration of 500 $\mu \mathrm{g} / \mathrm{mL}$ by following two methods. The percentage of antioxidant activity of the substances was assigned by DPPH free radical (2,2-diphenyl-1-picrilhydrazil) testing. The measurement of the DPPH radical scavenging activity was executed according to the methodology defined by Brand-Williams et al. (1995). A stock solution of DPPH $(200 \mu \mathrm{M})$ was prepared in methanol. The reaction mixture, containing $100 \mu \mathrm{L}$ of DPPH and $100 \mu \mathrm{L}$ of the diluted test sample, was incubated at $20^{\circ} \mathrm{C}$ for $120 \mathrm{~min}$. The absorbance expressed as the trolox equivalent was measured at $515 \mathrm{~nm}$. Percent DPPH radical scavenging activity was calculated as follows: Percentage of radical scavenging activity $=\{1-($ sample - blank $)($ control blank) $\} \times 100$. Ferric reducing antioxidant power (FRAP) analysis was performed to the method proposed by Benzie and Szeto (1999) for determining the antioxidant status, the calculation was made by using the standard curve drawn with iron sulphate.

\section{Statistical Analysis}

The data provided in the study were analyzed by t test and the values are explained as the mean \pm standard deviation (SD). The normality assumption of the data and the homogeneity of the variances were evaluated by the Shapiro Wilk test and evaluated by Levene test, respectively. SPSS 21.0 program was used in all statistical analyzes.

\section{Results and Discussion}

Since the dry matter levels of the fermented and nonfermented pomace were different, the comparison of both products was carried out on a $100 \%$ dry matter basis (Table $1)$. When the nutrients of the fermented tomato pomace were compared to the non-fermented pomace, significant increases were observed in all the examined nutrients $(\mathrm{P}<0.001)$. In the TP fermented by A. niger, $\mathrm{CP}$, ash and EE contents increased 56\%, 25\% (P =0.004) and 25\% $(\mathrm{P}=0.056)$, respectively. Also, this fermentation increased the $\mathrm{CF}, \mathrm{ADF}, \mathrm{NDF}$ and ADL contents at the ratios of $5.9 \%$, $6.4 \%, 21.0 \%$ and $36.2 \%$ respectively $(\mathrm{P}<0.001)$. However, the NFE and non-fiber carbohydrates (NFC) amounts decreased by $31.7 \%$ and $54.4 \%$, respectively $(\mathrm{P}<0.001)$. Some energy values such as TDN, DE, ME and net energy lactation $\left(\mathrm{NE}_{\mathrm{L}}\right)$ and some quality parameters (RFV and
RFQ) of the TP decreased by fermentation (approximately $2.5 \%$ of energy values and $23 \%$ for quality parameters ( $\mathrm{P}<0.001$, Table 2). Total phenolic content was slightly higher in FTP (96.36.73 mg GAE/g dry wt.) than in TP (87.20 GAE/g dry weight). While total phenolic content and antioxidant level did not increase, concentration of $\beta$ carotene and lycopene of TP decreased after fermentation with $A$ niger (Table 3).

The result of the present study indicated that solid state fermentation resulted in significant change in the nutrient content and nutritive value of TP. In general, nutrient contents of TP except for NFE and NFC increased, whereas, nutritive value decreased by $A$. niger fermentation. These results suggested that solid-state fermentation using A. niger was not enough effective in the substrate with high nutrient content due to the fact that an increase in the cellulose compounds such as ADF, NDF, ADL, hemicellulose and CF. Our results agree with Altop et al. (2019) who reported that the corresponding contents of sunflower meal and cottonseed meal increased by A. niger fermentation. Similar results have been reported in the studies on mango kernel (Kayode and Sani, 2008) and sour cherry kernel (Güngör et al. 2017). The increase in NDF and ADF of TP caused a decrease in feed consumption due to increase its volumetric capacity when used in animals, as determined herein. As such, it can be said that if the feed is rich in other nutrients as well as high CF content, the effect of fermentation may not be efficient on cellulosic ingredients. The results in some studies about the effect of SSF on sunflower meal (Jannathulla et al., 2018; Altop et al., 2019) and TP (Tosun, 2017) did not support this argument. The discrepancies between the results of previous studies and the present study may be attributed to substrate (particle size, initial moisture content and pretreatment), incubation conditions $(\mathrm{pH}$, relative humidity, temperature, agitation and aeration, additional $\mathrm{N}, \mathrm{P}$ and $\mathrm{C}$ supply) and microorganism used in the fermentation (strain, amount and sowing time), as reported by Pandey (2003) and Elibol and Moreira (2005). In a study relating to fermentation of TP with A. niger (Tosun, 2017), incubation parameters such as humidity, temperature, $\mathrm{pH}$ and fermentation duration were $91 \%, 28^{\circ} \mathrm{C}, 4-5$ and 72 hours, respectively, whereas corresponding parameters in our study were $60 \%, 24^{\circ} \mathrm{C}, 5$ and 168 hours.

While Assi and King (2008) reported that SSF increased the CP content of TP as reported herein, Tosun (2017) reported did not affect this nutrient. The increase in CP content of fermented TP may be resulted from the advanced mycelial growth of fungi used. Indeed, Altop (2019a) attributed that an increment in the CP content of the fermented sunflower meal and the hazelnut kernel meal resulted from increased A. niger spores during fermentation.

Microorganisms can derive energy from carbohydrates, alcohols, and amino acids (Sandle, 2016). Based on this information, it can be explained why there is an increase in $\mathrm{CP}$ and EE content. Indeed, in our research, NFE and NFC which were used as sources of energy by microorganisms reduced. The energy of the pomace could be enhanced proportionally due to the increase in the content of crude oil by fermentation, in contrast to our findings, EE levels of sunflower meal, cottonseed meal and soybean meal were reported to have decreased by the fermentation (Kumar and Kanwar, 2012; Jannathulla et al., 2018). Diminishing of EE contents could be 
attributed to lipase enzymes, which can be produced by $A$. niger in SSF (Kumar and Kanwar, 2012).

The ash content of the fermented TP was also increased. This increase was parallel to the increase in organic matter. At the end of the fermentation process, an increase in ash level of many products (olive leaf, tomato pulp, pomegranate peel and Larrea tridentata leaves) has been reported in the literature (Altop, 2019a; Assi and King, 2008; Aguilar et al., 2008). However, the results of this study are in contradiction with the study of Indian almonds (Apata, 2011) in which ash content decreases and TP (Tosun, 2017) and palm seed (Lawal et al., 2010), where ash content does not change. In this study, as a result of fermentation of dried TP with A niger inoculant, the amount of mineral substance increased due to increase protein and possibly enzyme production.

A. niger is known to be able to produce cellulase enzyme under fermentation conditions (Xie et al., 2016). It is thought that $\mathrm{CF}$ is used as an energy source and the decrease in $\mathrm{CF}$ and ADF content may be caused by this.
Many researchers have reported a decrease in the $\mathrm{CF}$ content of the products (Ginkgo biloba leaf, rapeseed meal, olive leaf) as a result of the fermentation process (Zhang et al., 2013; Shi et al., 2015; Xie et al., 2016; Altop, 2019a). However, our findings are similar to the studies on increasing the $\mathrm{CF}$ content of pomegranate bark and Larrea tridentata leaves (Aguilar et al., 2008), cassava bark (Okpako et al., 2008) and mango seed (Kayode and Sani, 2008). In SSF process, it is possible to decrease the amount of cellulose of tomato pomace and increase the amount of digestible nutrients. In addition, the cellulosic parts in the feed create a cage effect and reduce the digestion of amino acids, fatty acids, vitamins and minerals in digestive system of poultry (Ozturk, 2017).

The peel component of TP is rich in dietary fibre and lycopene, while the seed component contains high levels of oil and protein. All parts of TP, smashed, fermented or silage, can be used in animal nutrition (Lu et al., 2019). According to the reported results, the level of dietary fibre in tomato peels ranges from $62.8-88.5 \%$.

Table 1. Nutrient contents ( $\left.\mathrm{g} \mathrm{kg}^{-1} \mathrm{DM}\right)$ of tomato pomace (TP) before and after fermentation with Aspergillus niger $\left(\mathrm{X} \pm S_{x}^{-}\right)$

\begin{tabular}{l|ccccc}
\hline \multicolumn{1}{c|}{ Nutrients } & Unfermented TP & Fermented TP & Change, $\%$ & t-value & P-value \\
\hline DM (\%) & $829.8 \pm 1.50$ & $914.7 \pm 0.40$ & +10.23 & -56.642 & $<0.001$ \\
CP & $137.0 \pm 2.53$ & $213.7 \pm 12.36$ & +55.99 & -6.079 & 0.004 \\
EE & $28.15 \pm 0.9$ & $35.23 \pm 2.50$ & +25.15 & -2.663 & 0.056 \\
Ash & $105.73 \pm 3.73$ & $132.39 \pm 0.39$ & +25.22 & -7.171 & 0.002 \\
CF & $217.11 \pm 0.36$ & $230.01 \pm 1.76$ & +5.94 & -7.180 & 0.002 \\
NDF & $296.95 \pm 0.96$ & $359.19 \pm 1.59$ & +20.96 & -33.352 & $<0.001$ \\
ADF & $252.24 \pm 0.85$ & $268.41 \pm 0.13$ & +6.41 & -18.756 & 0.001 \\
ADL & $79.08 \pm 0.53$ & $107.71 \pm 1.13$ & +36.20 & -22.959 & $<0.001$ \\
Hemicellulose & $44.71 \pm 0.70$ & $90.78 \pm 3.39$ & +103.04 & -13.889 & $<0.001$ \\
NFE & $511.98 \pm 6.87$ & $388.64 \pm 12.71$ & -31.74 & 8.539 & $<0.001$ \\
NFC & $460.29 \pm 7.34$ & $294.69 \pm 11.13$ & -54.39 & 12.952 & $<0.001$ \\
Digestible DM & $69.26 \pm 1.49$ & $68.00 \pm 1.15$ & -1.85 & 0.666 & 0.542 \\
\hline Digesic DM
\end{tabular}

Digestible DM of unfermented TP and fermented TP were calculated the formulation to "DDM \% $=88.9-(0.779 \times \%$ ADF $)$ ".

Table 2. Feed quality parameters and energy values of tomato pomace (TP) before and after fermentation with Aspergillus niger $\left(\mathrm{X} \pm S_{x}^{-}\right)$

\begin{tabular}{l|ccccc}
\hline \multicolumn{1}{c}{ Variables } & Unfermented TP & Fermented TP & Change, $\%$ & t-value & P-value \\
\hline DMI & $4.04 \pm 0.013$ & $3.34 \pm 0.015$ & -20.95 & 35.516 & $<0.001$ \\
DDM & $69.25 \pm 0.066$ & $67.99 \pm 0.010$ & -1.85 & 18.759 & $<0.001$ \\
RFV & $216.94 \pm 0.492$ & $176.09 \pm 0.753$ & -23.20 & 45.418 & $<0.001$ \\
RFQ & $242.48 \pm 0.464$ & $195.46 \pm 0.824$ & -24.06 & 49.717 & $<0.001$ \\
TDN & $73.81 \pm 0.097$ & $71.96 \pm 0.015$ & -2.56 & 18.756 & $<0.001$ \\
DE & $3.25 \pm 0.004$ & $3.17 \pm 0.001$ & -2.56 & 18.756 & $<0.001$ \\
ME & $2.66 \pm 0.004$ & $2.60 \pm 0.001$ & -2.58 & 18.756 & $<0.001$ \\
NEL $^{\text {D }}$ & $1.69 \pm 0.0024$ & $1.64 \pm 0.0004$ & -2.74 & 18.756 & $<0.001$ \\
\hline
\end{tabular}

DMI (\% of body weight): dry matter intake, DDM (\%): digestible dry matter, RFV: relative feed value, RFQ: relative forage quality, TDN (\%): total digestible nutrient, $\mathrm{DE}\left(\mathrm{Mcal} \mathrm{kg}^{-1}\right)$ : digestible energy, $\mathrm{ME}\left(\mathrm{Mcal} \mathrm{kg}^{-1}\right)$ : metabolizable energy, $\mathrm{NE}_{\mathrm{L}}\left(\mathrm{Mcal} \mathrm{kg}^{-1}\right)$ : net energy lactation

The primary valuable components in the seed and peel are extremely different. The peel is rich in dietary fibre, lycopene and phenols and the seed mainly comprises of oil and protein (Lu et al., 2019). The decrease in total dietary fibre content is composed of soluble dietary fibre and insoluble dietary fibre content which are important for digestion and absorption of the nutrients in human and animal nutrition. Navarro et al. (2011) showed that tomato peel fiber is rich in insoluble fiber and can be used as a food supplement to improve the physical, chemical and nutritional properties of potentially added foods. Despite this information, it has been reported that tomato peel (1: 5) values are not high in terms of soluble dietary fiber / insoluble dietary fiber (Navarro-Gonzalez et al., 2011). These levels are mainly calculated for ruminant animals, so excessive addition of TP may negatively affect the growth of non-ruminant animals (Lu et al., 2019).

Increase in NDF and ADL levels may be due to the effect of the fungal strain, the medium used and the environmental factors in the fermentation. Because of the presence of cellulose and chitin in the cell wall structure of fungi (Arda 2000), it is thought that fermentation causes an increase in NDF, ADL rates and the strain used as an inoculant does not work enough on hemicellulose and 
lignin. Also Beauvais et al. (2014), reported that cellulosic components increased by the fermentation because of the fact that the cell wall of $A$. Niger contains chitin, cellulose like component. However, Altop et al. (2019), reported that SSF increased the CF, ADF, ADL content of sunflower meal and NDF, ADF and ADL content of cottonseed meal. Similar results were reported in the studies on sour cherry kernel (Güngör et al., 2017), mango kernel (Kayode and Sani, 2008). The increase in the NDF level is not lined with the results reported for tomato pomace (Tosun, 2017), olive leaf (Altop, 2019a) and rapeseed meal (Shi et al., 2015).

In this trial, a reduction in the NFE content of fermented tomato pomace may be related to the fact that fungi prefer primarily easily soluble carbohydrates such as glucose, sucrose and starch as a carbon source (Papagianni, 2007). However, it is concluded that the increase in the cell wall elements may increase proportionally due to the decrease of NFE used to meet the energy needs. The present study contradicts the study of Tosun (2017), who reported that the NFE content of tomato pomace increased. This alteration in nutrient composition caused by SSF application may be due to different types of tomato and growing environment, as well as the proportion of peel, seed or pulp inside the fruit (Savadkoohi and Farahnaky, 2012; Fuentes et al., 2013). The quantities of nutrients such as cellulose, as well as the fractions they contain, can cause large differences in the nutritive value of TP (Fuentes et al., 2013; Giuffrè and Capocasale, 2016; Mechmeche et al., 2017). These fraction differences can also greatly alter the digestibility of the product and affect the use of TP. Not every TP is expected to have similar nutrient content, but there are also considerable variations in research at a particular component level. Del Valle et al. (2006) reported fiber, protein, ash and oil values in tomato pomace as 59.03, 19.27, 3.92 and 5.85 respectively, the same ingredients were 39.11, 24.67, 5.29 and 9.87 respectively according to research by Savadkoohi and Farahnaky (2012). Also, Fuentes et al. (2013) indicated that these nutrient ingredients of TP were 46.00, 16.00, 4.00 and 2.00. Furthermore, variations in the variety, maturity and growth conditions create differences in the chemical composition of TP.

While fermentation increases the dry matter, protein, fat, ash values from $25 \%$ to $55 \%$, the increases in CF, NDF, $\mathrm{ADF}$ and ADL did not positively affect the digestibility of the feed. In order to clarify this conflicting situation, it is necessary to determine how the feed value changes. For this purpose, relative feed value (RFV), which the index ranks forage relative to the digestible DMI of full bloom alfalfa, was determined (Table 2). RFV index calculates DDM of the alfalfa from ADF, and estimates the DM intake potential from NDF (Jeranyama and Garcia 2004). Since the digestive level of ADF is very slow, it is desirable to have low amounts in the diet. When the RFV numbers of 216.94 and 176.09 calculated in the unfermented and fermented TP are compared to full bloom alfalfa hay, which has a RFV of $100 \%$, it is seen that TP is a high quality plant. A comparison, according to RFV shows that the application of solid state fermentation does not improve feed digestibility. RFV is a measure of forage intake and energy value. Relative feed value increases as forage quality increases. But, RFV of a forage does not take into account the protein content of the forage. On the other hand, when feeds with a similar RFV index are fed, differences in the digestibility of cellulosic compounds be able to result in a difference in animal performance. The RFQ index was developed to eliminate this difference. This index allowances the differences in digestibility of the cellulosic compounds and to be able to use to more effectively estimate animal performance and satisfy animal needs (Jeranyama and Garcia 2004). As in TDN, energy value calculation methods are more reliable methods for determining the nutritional value of feeds, taking into account nutrients such as CP, EE, ash and NDF. However, when considered the value TDN, DE, ME, NEL and RFQ of TP proves that the application of SSF didn't increase the digestibility of the feed and contributes positively to its usability as feed material in animal nutrition (Table 2). Energy values (TDN, DE, ME and NEL) of the feed decreased by $2.5 \%$, DMI and DDM decreased by $20.95 \%$ and $1.8 \%$ by fermentation method, respectively. On the other hand, RFV and RFQ values decreased by $23.20 \%$ and 24.06, respectively. Although there is a decrease in RFV and RFQ values, it shows that TP, which already has very high RFV and RFQ values, does not need SSF treatment compared to alfalfa.

Tomatoes and its byproducts are also a potentia source of carotenoids, especially lycopene. Lycopene as antioxidant agent and coloring in the cosmetics, and its use in pharmaceutical and food industries has expanded in the recent years. There has been demonstrated that tomatoes and its derivatives, rich the lycopene content to be in the range of 2.62 to $629 \mathrm{mg} / 100 \mathrm{~g}$ (Baranska et al., 2006) fresh weight basis. While lutein content could not detect, lycopene and $\beta$-carotene contents decreased when fermented the tomato pomage in this trial. Total phenolic content, antioxidant status and antioxidant levels of TP did not increase after fermentation with $A$ niger (Table 3 ). Total phenolic content was slightly higher in FTP (96.36 mg GAE/g dry wt.) than in TP (87.17 GAE/g dry weight). In contrast to our study, extraction of lycopene was increased effectively under SSF process (Jamal et al., 2017). Thus, cellulase produced from fermentation was used to disrupt the cell wall components that facilitate the separation of intracellular components (Ranveer et al., 2013). Also Tosun (2017) reported that total phenolic content and antioxidant capacity of apple and TP increased by fermentation with $\mathrm{A}$. niger and $\mathrm{P}$. Chrysosporium. Fermentation increases the phenolic compounds of feed, thereby reducing tannins, fibres and enriching with enzymes, organic acids and color substances (Gungor et al., 2017, Gungor and Erener, 2020b). However, Altop (2019a) reported that although the oleuropein content of fermented olive leaves was decreased, it's catechin and hydroxytyrosol contents were increased by SSF. This increase in the starch and sugar contents might be attributed the sugars released from the hydrolysis of phenolic compounds during fermentation (Altop 2019a). The increased concentrations of protein after fermentation are thought to have a relation to the increased antioxidant level (Amadou et al., 2011). Concentrations of phenolic ingredients also improve in SBM after fermentation, thereby increasing metal chelating activity and antioxidant (Moktan et al., 2008). On the other hand, bacterial, fermentation has ahigher antioxidant activity, too (Jemil et al., 2016). Aguilar et al. (2008) reported that pomegranate peel and creosote bush leaves are good sources of SSF and 
antioxidants. As a result of fungal fermentation, it was determined that high level of gallic acid and catechin in creosote bush leaves and ellagic acid accumulation in pomegranate peels (Aguilar et al., 2008). The maturation stage of the tomato fruit affects the antioxidant level, whereas antiplatelet activity can act independently of fruit maturity. Fuentes et al. (2013) stated that tomato and its byproducts may be sources that provide highly effective antioxidant and antiplatelet activity. Contrary to antiplatelet activity, it has been determined that the antioxidant activity change indpentdently from ripening of tomato. According to these findings, extracts from both seed mucilage and pomacecan be used as functional components. These can be added as supplements to provide unprocessed foods with antioxidant and antiplatelet activities in preventing noncommunicable chronic diseases (Fuentes et al., 2013). Tomato peel could be noted as the source of insoluble hemicelluloses and compounds with antioxidant properties like lycopene, rutin, and chlorogenic acids. Tomato fiber can be used as a thickening or texturizing, fiber source and / or as an antioxidant enhancer with its low-fat content (Navarro et al., 2011).

Table 3. Total phenolic content, antioxidant status and antioxidant levels and carotenoid contents of tomato pomace (dry matter basis) before and after fermentation with Aspergillus niger $\left(\mathrm{X} \pm S_{x}^{-}\right), \mathrm{n}=3$

\begin{tabular}{l|cccc}
\hline \multicolumn{1}{c|}{ Nutrients } & Unfermented TP & Fermented TP & t value & P-value \\
\hline Total phenolics* & $87.17 \pm 1.61$ & $96.36 \pm 3.81$ & -1.852 & 0.138 \\
Antioxidant status** & $49.86 \pm 1.68$ & $48.43 \pm 0.35$ & 0.025 & 0.981 \\
Antioxidant level *** & $38.08 \pm 1.04$ & $38.35 \pm 0.36$ & 0.082 & 0.939 \\
Lycopene $(\mu \mathrm{g} / 100 \mathrm{~g})$ & $14478.80 \pm 142.89$ & $2876.00 \pm 4.12$ & 81.170 & $<0.001$ \\
$\beta$-carotene $(\mu \mathrm{g} / 100 \mathrm{~g})$ & $2460.0 \pm 30.57$ & $1861.97 \pm 12.36$ & 18.965 & $<0.001$ \\
Lutein & $\mathrm{ND}$ & $\mathrm{ND}$ & - & - \\
\hline *: gallic acid $(\mathrm{mg}$ GAE/g dry wt), **: as FRAP (mmol FeSO4 E/g), ***: as DPPH, (mmol TE/g) trolox equivalent, ND: No determine TE
\end{tabular}

These findings from the literature showed that TP can be used in animal feed and food components in various ways, as it is rich in nutrients and functional components such as lycopene, dietary fiber, pectin, fat and protein. The contradictory results mentioned above showed that the effectiveness of TP as a feed ingredient may vary depending on many factors. Numerous factors such as animal species, relative feeding quality of basal feeds, TP forms such as fresh, dried and ensiled and length of feeding time should be reviewed in the evaluation of TP (Lu et al., 2019).

\section{Conclusion}

The results of the present study indicated that: i) the $A$. niger strain used as inoculant in the study worked in harmony with the dried tomato pomace used as substrate for $\mathrm{CP}, \mathrm{EE}$ and minerals. ii) Increasing in $\mathrm{CP}$ content by $55.99 \%$ due to fermentation is thought to be largely due to microbial protein. It has been found that $A$. Niger may be a suitable fermenter to increase the crude protein content in TP. iii) Increasing the EE content of the pomace (25.15\%) by $A$. niger fermentation, the energy value of tomato pulp can be increased slightly. iv) NFE and NFC values of tomato pomace decreased by $31.74 \%$ and $54.39 \%$, respectively. This decrease is thought to occur because the microorganism prefers easily soluble and digestible carbohydrates as carbon and energy sources. v) The amount of $\mathrm{CF}$ and $\mathrm{ADF}$ increased around 6\% with fermentation of tomato pomace. Also, the unexpected increase in NDF and ADL rates is thought to be due to the cell wall composition. vi) While total phenolic content and antioxidant level did not increase, concentration of $\beta$ carotene and lycopene of TP decreased after fermentation with A niger. Total phenolic content was slightly higher in FTP (96.36 mg GAE/g dry wt.) than in TP (87.17 GAE/g dry weight).

This experiment showed that TP can be used as a high value added product in animal feeds by enriching with protein, ether extracts and minerals. However, the A. niger strain used in this experiment was not able to reduce cellulosic products and therefore did not positively contribute to digestibility. However, TP have good nutritional and functional qualities, not only due to their high vitamin and mineral content, but also because of phytochemicals, notably the lycopene and also the high RFV and RFQ values, it can be interpreted as TP does not require $\mathrm{SSF}$ application.

\section{Abbreviations}

ADF: Acid detergent fiber; ADL Acid detergent fiber; ATCC: American Type Culture Collection; BW: Body weight; $\mathrm{CF}$ : Crude fiber; $\mathrm{CP}$ : Crude protein; DDM: Digestible dry matter; DE: Digestible energy; DM: Dry matter; DMI: Dry matter intake; DPPH: Free radical (2,2diphenyl-1-picrilhydrazil); EE: Ether extract; EE: Ether extract; FRAP: Ferric reducing antioxidant power; FTP: Fermented tomato pomage; GAE: Gallic acid equivalent; ME: Metabolizable energy; ND: No determine; NDF: Neutral detergent fiber; $\mathrm{NE}_{\mathrm{L}}$ Net energy lactation; NFC: Non-fiber carbohydrates; NFE: Nitrogen-free extract; RFQ: Relative feed quality; RFV: Relative Feed Value; SD: Standard deviation; SSF: Solid-state fermentation; TD: Trade mark; TDN: Total digestible nutrients; TE: Trolox equivalent

\section{Acknowledgments}

The authors would like to thank Mr. Aydin Altop for the fermenting of the tomato pomage, and Mrs. İlkay Koca for the analysis of the phenolic content and antioxidant levels of tomato pomace. This article is summarized from Kerim Demirgul's MSc thesis conducted under the supervision of Ergin Ozturk.

\section{Funding}

This research did not receive any specific grant from funding agencies in the public, commercial, or not-forprofit sectors. 


\section{Conflict of Interest}

The authors declare that they have no conflict of interest, and this document is their original research work done at the Agricultural Research and Application Centre of the Ondokuz Mayis University, Samsun, Turkey.

\section{Authors' contributions}

EO conceived and designed the experiment. EO and $\mathrm{KD}$ performed the experiment. $\mathrm{EO}$ and $\mathrm{KD}$ performed the laboratory analysis. EO wrote the manuscript. All authors read, critically revised for intellectual contents and approved the final manuscript.

\section{Availability of data and materials}

All data generated or analyzed are available from the corresponding author on request.

\section{Ethics approval and consent to participate}

Not applicable.

\section{Consent for publication}

Not applicable.

\section{References}

Aguilar CN, Aguilera-Carbo A, Robledo A, Ventura J, Belmares R, Martinez D, Rodríguez-Herrera R, Contreras J. 2008. Production of antioxidant nutraceuticals by solid-state cultures of pomegranate (Punica granatum) peel and creosote bush (Larrea tridentata) leaves. Food Technology and Biotechnology 46(2): 218-222.

Altop A. 2019a. Effect of solid-state fermentation on main nutritional components, some minerals, condensed tannin and phenolic compounds of olive leaves. Turkish Journal of Agriculture Food Science and Technology 7(1): 115-119.

Altop A. 2019b. The effects of diets supplemented with fermented or non-fermented cherry kernels (Prunus avium L.) on growth performance, ileal histology, caecum microflora, and some meat quality parameters in broiler chickens. European Poultry Science 260, 83 doi:10.1399/eps.

Altop A, Gungor E, Erener E. 2019. Improvement of nutritional quality of some oilseed meals through solid-state fermentation. Turkish Journal of Agriculture - Food Science and Technology 7(9): 1411-1414.

Alves AR, Beelen PMG, de Medeiros AN, Neto SG, Beelen RN. 2011. Consumo e digestibilidad do feno de sabia por caprinos e ovinos suplementados com polietilenoglico. Revista Caatinga 24: 152-157.

Amadou I, Le GW, Shi YH, Jin S. 2011. Reducing, radical scavenging, and chelation properties of fermented soy protein meal hydrolysate by Lactobacillus plantarum Lp6. International ournal of Food Properties 14: 654-665.

Apata DF. 2011. Effect of Terminalia catappa fruit meal fermented by Aspergillus niger as replacement of maize on growth performance, nutrient digestibility, and serum biochemical profile of broiler chickens. Biotechnology Research International 907546, doi:10.4061/2011/907546.

Arda M. 2000. Basic Microbiology. Chapter 9, Medisan Publication, 45, Ankara.

Assi JA, King AJ. 2008. Manganese amendment and Pleurotus ostreatus treatment to convert tomato pomace for inclusion in poultry diets. Poultry Science 87(9): 1889-1896.
Baranska M, Schütze W, Schulz H. 2006. Determination of Lycopene and $\beta$-carotene content in tomato fruits and related products: Comparison of FT-Raman, ATR-IR, and NIR Spectroscopy. Analytical Chemistry 78(24): 8456-8461.

Beauvais A, Fontaine T, Aimanianda V, Latgé JP. 2014. Aspergillus cell wall and biofilm. Mycopathologia 178(5-6): 371-377.

Benzie IF, Szeto Y. 1999. Total antioxidant capacity of teas by the ferric reducing/antioxidant power assay. Journal of Agricultural and Food Chemistry 47(2): 633-636.

Brand-Williams W, Cuvelier ME, Berset C. 1995. Use of a free radical method to evaluate antioxidant activity. LebensmittelWissenschaft und -Technologie 28(1): 25-30.

Del Valle M, Cámara M, Torija ME. 2006. Chemical characterization of tomato pomace. Journal of the Science of Food and Agriculture 86: 1232-1236.

Demiray E. 2009. Determination of lycopene, ß-Carotene, ascorbic acid and color change kinetics of tomatoes in drying process. MSc Thesis, Pamukkale Üniversitesi Fen Bilimleri Enstitüsü Gıda Mühendisliği Anabilim Dalı, 101, Denizli.

Elibol M, Moreira A. 2005. Optimising some factors affecting alkaline protease production by a marine bacterium Teredinobacter turnirae under solid substrate fermentation. Process Biochemistry 40(5): 1951-1956.

FAO, 2019. Food and Agriculture Organization. Available from: http://www.fao.org/faosta. Accessed date: 29.09.2019.

Fuentes E, Carle R, Astudillo L, Guzman L, Gutierrez M, Carrasco G \& Palomo I. 2013. Antioxidant and antiplatelet activities in extracts from green and fully ripe tomato fruits and pomace from industrial tomato processing. Evidencebased Complementary and Alternative Medicine 867578 . https://doi.org/10.1155/2013/867578.

Giuffrè AM, Capocasale M. 2016. Physicochemical composition of tomato seed oil for an edible use: The effect of cultivar. International Food Research Journal 23: 583-591.

Güngör E, Erener G. 2020a. Effect of dietary raw and fermented sour cherry kernel (Prunus cerasus L.) on growth performance, carcass traits, and meat quality in broiler chickens. Poultry Science 99(1): 301-309. https://doi.org/ $10.3382 / \mathrm{ps} / \mathrm{pez} 490$

Güngör E, Erener G. 2020b. Effect of dietary raw and fermented sour cherry kernel (Prunus cerasus L.) on digestibility, intestinal morphology and caecal microflora in broiler chickens. Poultry Science 99(1): 471-478. https://doi.org/ $10.3382 / \mathrm{ps} / \mathrm{pez} 538$

Güngör E, Altop A, Öztürk E, Erener G. 2017. Nutritional Changes of Sour Cherry (Prunus cerasus) Kernel Subjected to Aspergillus niger Solid-state Fermentation. Journal of Tekirdag Agricultural Faculty 6: 99-103.

Jamal P, Hashlamona A, Jaswir I, Akbar I, Nawawi WMFW. 2017. Extraction of lycopene from tomato waste using solid state fermentation. International Food Research Journal 24(Suppl): 416-421.

Jannathulla R, Dayal J S, Ambasankar K, Muralidhar M. 2018. Effect of Aspergillus niger fermented soybean meal and sunflower oil cake on growth, carcass composition and haemolymph indices in Penaeus vannamei Boone, 1931. Aquaculture 486: 1-8

Jemil N, Ayed HB, Manresa A, Nasri M, Hmidet N. 2017. Antioxidant properties, antimicrobial and anti-adhesive activities of DCS1 lipopeptides from Bacillus methylotrophicus DCS1. BMC Microbiology 17: 144 doi 10.1186/s12866-017-1050-2.

Jeranyama P, Garcia AD. 2004. Understanding relative feed value (RFV) and relative forage quality (RFQ). Cooperative Extension Service. ExEx8149. College of Agriculture and Biological Sciences, South Dakota State Unıversity, USDA. 
Kaur D, Wani AA, Oberoi DPS, Sogi DS. 2008. Effect of extraction conditions on lycopene extractions from tomato processing waste skin using response surface methodology. Food Chemistry 108: 711-718 https://doi.org/10.1016/ j.foodchem. 2007.11.002.

Kayode R, Sani A. 2008. Physicochemical and proximate composition of mango (Mangifera indica) kernel cake fermented with mono-culture of fungal isolates obtained from naturally decomposed mango kernel. Life Science Journal 5(4): 55-63.

Lawal T, Iyayi E, Adeniyi B, Adaramoye O. 2010 Biodegradation of palm kernel cake with multienzyme complexes from fungi and its feeding value for broilers. International Journal of Poultry Science 9(7): 695-701.

Lu Z, Wang J, Gao R, Ye F, Zhao G. 2019. Sustainable valorisation of tomato pomace: A comprehensive review. Trends in Food Science and Teechnology 86: 172-187.

Mechmeche M, Kachouri F, Chouabi M, Ksontini H, Setti K, Hamdi M. 2017. Optimization of extraction parameters of protein isolate from tomato seed using response surface methodology. Food Analytical Methods 10: 809-819 https://doi.org/10.1007/s12161-016-0644-x.

Moktan B, Saha J, Sarkar PK. 2008. Antioxidant activities of soybean as affected by Bacillus-fermentation to kinema. Food Research International 41: 586-593.

Navarro-Gonzalez I, Garcia-Valverde V, Garcia-Alonso J, Periago MJ. 2011. Chemical profile, functional and antioxidant properties of tomato peel fiber. Food Research International 44, 1528-1535 https://doi.org/10.1016/ j.foodres.2011.04.005

Nour VD, Panaite T, Ropota M, Turcu R, Trandafir I, Corbu AR. 2018. Nutritional and bioactive compounds in dried tomato processing waste, CyTA. Journal of Food 16(1): 222-229.

Okpako C, Ntui V, Osuagwu A, Obasi F. 2008. Proximate composition and cyanide content of cassava peels fermented with Aspergillus niger and Lactobacillus rhamnosus. Journal of Food Agriculture and Environment 6(2): 251-255.

Ozturk E. 2017. Performance of broilers fed with different levels of sunflower meal supplemented with or without enzymes. Indian Journal of Animal Research 51(3): 495-500 doi:10.18805/ijar.v0i0f.3799.

Pandey A. 2003. Solid-state fermentation. Biochemical Engineering Journal 13(2-3): 81-84.

Papagianni M. 2007. Advances in citric acid fermentation by Aspergillus niger biochemical aspects, membrane transport and modeling. Biotechnology Advances 25(3): 244-263.
Ranveer RC, Patil SN, Sahoo AK. 2013. Effect of different parameters on enzyme-assisted extraction of lycopene from tomato processing waste. Food and Bioproducts Processing 91(4): 370-375.

Sandle T. 2016. Microbiological challenges to the pharmaceuticals and healthcare. In Pharmaceutical Microbiology, Essentials for Quality Assurance and Quality Control, Publisher: Elsevier, ISBN: 9780081000229, pp: 281-294.

Savadkoohi S, Farahnaky A. 2012. Dynamic rheological and thermal study of the heat-induced gelation of tomato seed proteins. Journal of Food Engineering 113: 479-485 https://doi.org/ 10.1016/j.jfoodeng.2012.06.010.

Shi C, He J, Yu J, Yu B, Huang Z, Mao X, Zheng P, Chen D. 2015. Solid state fermentation of rapeseed cake with Aspergillus niger for degrading. Journal of Animal Science and Biotechnology 6(13): 1-7 doi:10.1186/s40104-015-0015-2.

Singleton VL, Rossi JA. 1965. Colorimetry of total phenolics with phosphomolybdic-phosphotungstic acid reagents. American journal of Enology and Viticulture 16(3): 144-158.

Tosun R. 2017. Making the nutrient composition of apple and tomato pulp subjected to solid-phase fermentation by fungal microorganisms useful for poultry. MSC Thesis, Süleyman Demirel University, Institute of Science, Animal Science Department, 91pages, Isparta, Turkey.

Undersander D. 2003. The new forage quality index-concepts and use, World's Forage Superbowl Contest. http://www.dfrc.ars.usda.gov/WDExpoPdfs/newRelativeFQi ndex.pdf, Accessing date: 17 March 2020.

Van Soest P, Robertson J, Lewis B. 1991. Methods for dietary fiber, neutral detergent fiber, and nonstarch polysaccharides in relation to animal nutrition. Journal of Dairy Science 74(10): 3583-359.

Verzelloni E, Tagliazucchi D, Conte A. 2007. Relationship between the antioxidant properties and the phenolic and flavonoid content in traditional balsamic vinegar. Food Chemistry 105(2): 564-571.

Xie P, Huang L, Zhang C, Zhang Y. 2016. Nutrient assessment of olive leaf residues processed by solid-state fermentation as an innovative feedstuff additive. Journal of Applied Microbiology 121(1): 28-40.

Zhang X, Zhao L, Cao F, Ahmad H, Wang G, Wang T. 2013. Effects of feeding fermented Ginkgo biloba leaves on small intestinal morphology, absorption, and immunomodulation of early lipopolysaccharide-challenged chicks. Poultry Science 92(1): 119-130.

Zuorro A, Fidaleo M, Lavecchia R. 2011. Enzyme-assisted extraction of lycopene from tomato processing waste. Enzyme and Microbial Technology 49: 567-573. 